\title{
ANALISIS KADAR BILIRUBIN SERUM BAYI YANG MENGALAMI IKTERUS NEONATUS
}

\author{
Ni Putu Purnamiati \\ Universitas Pendidikan Ganesha \\ Singaraja, Indonesia \\ e-mail: purnamiatinpt@gmail.com
}

\begin{abstract}
Abstrak
Penelitian ini adalah penelitian deskriptif yang bertujuan untuk: (1) mengetahui kadar bilirubin indirect serum bayi yang mengalami ikterus neonatus, dan (2) persentase hiperbilirubinemia pada bayi yang mengalami ikterus neonatus. Subyek penelitian ini adalah serum bayi yang mengalami ikterus neonatus, sedangkan obyek penelitian ini adalah kadar bilirubin indirect serum bayi yang mengalami ikterus neonatus. Penelitian ini dilakukan di Laboratorium Patologi Klinik Rumah Sakit Sanglah Denpasar dari tanggal 14 Juni 2005 sampai dengan 25 Juni 2005. Hasil penelitian menunjukkan bahwa (1) kadar bilirubin indirect serum bayi yang mengalami ikterus neonatus adalah $5,81 \mathrm{mg} / \mathrm{dL}$ sampai $28,7 \mathrm{mg} / \mathrm{dL}$ dan (2) persentase terjadinya hiperbilirubinemia pada bayi yang mengalami ikterus neonatus adalah $50 \%$.
\end{abstract}

Kata kunci: Bilirubin, Ikterus Neonatus

\section{Pendahuluan}

Ikterus neonatus adalah suatu keadaan dimana sklera, kulit atau jaringan lain dari bayi berwarna kuning akibat penimbunan bilirubin dalam tubuh (Hasan, R. et. al. 1985). Ikterus merupakan akibat dari peningkatan kadar bilirubin indirect ("unconjugated") atau kadar bilirubin direct ("conjugated") dalam darah (Hasan, R. et. al. 1985). Ikterus dapat berupa suatu gejala fisiologis (terdapat pada 25-50\%) pada bayi baru lahir yang cukup bulan, dan akan lebih tinggi pada bayi yang kurang bulan (prematur). Selain itu, ikterus dapat merupakan hal yang patologis (penyakit) misalnya pada ketidakcocokan Rhesus dan golongan darah ( $\mathrm{ABO}$ ). Ikterus patologis adalah ikterus yang mempunyai dasar penyakit atau kadar bilirubinnya mencapai suatu nilai yang disebut dengan hiperbilirubinemia. Batas minimum kadar bilirubin indirect serum bayi yang lahir kurang bulan (prematur) pada kasus ini adalah $10 \mathrm{mg} / \mathrm{dL}$ dan akan lebih tinggi pada bayi yang lahir cukup bulan yaitu $12 \mathrm{mg} / \mathrm{dL}$ (Hasan, R. et. al, 1985).

Hasil penelitian yang dilakukan di Rumah Sakit Dr. Cipto Mangunkusumo Jakarta Menunjukkan bahwa jumlah penderita ikterus neonatus pada bayi sangat tinggi berkisar antara $50 \%$ sampai $75 \%$ (Wiknjosastro, H. 1997). Terhadap bayi yang mengalami ikterus neonatus diperoleh persentase kasus hiperbilirubinemia adalah 62,32\%, dimana kadar Bilirubin Indirectnya melebihi $10 \mathrm{mg} / \mathrm{dL}$. Penelitian dengan hasil yang sama juga diperoleh oleh Sirripoonya di Bangkok tahun 1967 (Wiknjosastro, H. 1997).

Penelitian ini dilakukan di Rumah Sakit Sanglah Denpasar karena Rumah Sakit ini merupakan Tipe B Pendidikan dan terlengkap di Bali yang memiliki fasilitas pendukung untuk melakukan pemeriksaan bilirubin serum bayi. Bayi yang mengalami ikterus neonatus di Rumah Sakit Sanglah Denpasar cukup banyak, dan sangat sering terjadi pada bayi baru lahir, sehingga penelitian ini perlu dilakukan kajian mendalam mengenai kadar bilirubin indirect serum bayi yang menderita ikterus neonatus dan persentase kasus hiperbilirubinemia pada bayi yang mengalami ikterus neonatus di Rumah Sakit Sanglah Denpasar.

\section{Metode}

Penelitian ini merupakan penelitian deskriptif untuk mengetahui kadar bilirubin indirect serum bayi yang mengalami ikterus neonatus, dan untuk mengetahui persentase bayi yang tergolong hiperbilirubinemia.

Subjek penelitian ini adalah serum darah bayi yang mengalami ikterus neonatus. Sedangkan, obyek penelitian ini kadar bilirubin indirect serum bayi yang mengalami ikterus neonatus yang diperiksa di Laboratorium Patologi Klinik Rumah Sakit Sanglah Denpasar 
Penelitian ini dilakukan pada Sub laboratorium Kimia Klinik Rumah Sakit Sanglah Denpasar dari tanggal 1 Juni 2005 sampai dengan tanggal 14 Juni 2005 selama waktu pelaksannan Praktek Kerja peneliti. Instrumen yang digunakanadalah Beckman Coulter CX 7 yang merupakan suatu alat autoanalyzer yang dapat menghitung kadar bilirubin serum secara langsung, dan merupakan suatu alat spektrofotometer yang canggih

Alat yang disiapkan untuk digunakan dalam penelitian ini adalah sebagai berikut: Alat Beckman Coulter CX, Sample Cup sebanyak 20 buah, Sector khusus alat Beckman Coulter CX 7 sebanyak 3 buah. Bahan yang disiapkan adalah sebagai berikut: Serum bayi baru lahir yang menjadi subyek penelitian, R1: Reagen diazo I, 4-Asam Aminobenzena Sulfat, Asam Klorida, R2: Reagen diazo II, Natrium Nitrat, R3 : Akselerator (Kafein, Natrium Benzoat, Natrium Nitrat), R4: Larutan Fehling II, Na-K tartarat, $\mathrm{NaOH}$, Serum kontrol untuk pemeriksaan bilirubin serum, Multikalibrator. Data yang diperoleh dalam penelitian ini adalah data tentang kadar bilirubin indirect dalam serum bayi yang mengalami ikterus neonatus.

Tahap-tahap pengumpulan data yang dilakukan dalam penelitian ini adalah sebagai berikut. Pada tahap ini dilakukan persiapan alat, bahan, dan serum yang akan diperiksa. Serum yang digunakan dalam penelitian ini adalah berasal dari Sub laboratorium Sampling dan Prosesing Laboratorium Patologi Klinik Rumah Sakit Sanglah Denpasar. Sampel darah bayi yang diambil dari bangsal bayi Rumah Sakit Sanglah Denpasar telah memenuhi ketentuan sebagai berikut: 1) Bayi yang akan diperiksa kadar bilirubin serumnya tidak mendapatkan obat yang dapat mempengaruhi kadar bilirubin setelah bayi tersebut lahir, 2) Pada saat pengambilan sampel darah, bayi diletakkan pada posisi tidur terlentang, 3) Pemasangan tourniquet pada lengan bayi tidak boleh melebihi 1 menit karena hal ini dapat menyebabkan hemolisis, 4) Darah bayi dipusingkan hingga menjadi serum, dan ditempatkan pada sample cup yang telah diberi kode.

Serum bayi yang diterima dari Sub lab Sampling dan Prosesing ini selanjutnya diperiksa kondisinya. Jika terdapat darah yang membeku, maka bekuan darah tersebut dikeluarkan dengan lidi kering yang sudah disterilisasi. Jika terdapat serum bayi yang lisis segera dilaporkan ke bagian Sub lab Sampling untuk dilakukan pengambilan darah ulang. Jika terdapat gelembung pada serum, maka dihilangkan dengan cara meniup serum tersebut. Serum yang telah berada dalam sample cup selanjutnya ditempatkan pada sector. Selanjutnya serum siap dianalisis.

Pada tahap ini dilakukan pengukuran kadar bilirubin serum bayi dengan alat Beckman Coulter $C X$ 7. Sebelum digunakan untuk memeriksa serum, alat tersebut dikalibrasi dan dikontrol terlebih dahulu dengan multikalibrator dan serum kontrol. Kalibrasi dan kontrol dilakukan dengan cara sebagai berikut: 1) Serum kontrol dan kalibrator ditempatkan pada sample cup. Multikalibrator pada sample cup 1, serum kontrol bilirubin pada sample cup 2, 2) Sample cup ditempatkan pada sector alat Beckman Coulter CX7, 3) Sector dimasukkan pada piringan tempat sampel pada Beckman Coulter CX 7, 4) Pada komputer alat Beckman Coulter CX7 ditekan "F1" kemudian dimasukkan nomor sector yang digunakan, tekan "enter", 5) Identitas bahan yang akan diperiksa dimasukkan yaitu dengan cara sebagai berikut "tanggal pemeriksaan/bulan pemeriksaan/kode pada sample cup". Misalnya, untuk multikalibrator yang diukur tanggal 1 Juni 2005 identitasnya adalah "1/5/1". Kemudian pada komputer alat Beckman Coulter CX7 lalu tekan "enter", 6) Pada komputer alat Beckman Coulter CX7 ditekan "F6". Kemudian dipilih parameter yang akan dikontrol yaitu bilirubin total dan bilirubin direct. Lalu tekan "enter", 7) Jika pada layar computer alat Beckman Coulter CX7 telah tampil "stand by", maka tekan "start" pada komputer alat. Dengan demikian alat akan melakukan pemeriksaan secara otomatis, 8) Hasil pemeriksaan kalibrasi dicetak dengan cara sebagai berikut. Kontrol alat ditekan "F2" pada komputer alat Beckman Coulter CX7.

Setelah dilakukan kalibrasi dan kontrol maka dilakukan pemeriksaan kadar bilirubin pada serum bayi. Pemeriksaan dilakukan dengan cara sebagai berikut (Anonim. 2004). 1) Serum bayi yang telah berada pada sector ditempatkan pada piringan tempat alat yang terdapat pada alat Beckman Coulter CX 7, 2) Alat Beckman Coulter CX7 diposisikan pada kondisi stand by dengan cara menekan "view screen" pada komputer alat, 3) Pada komputer alat Beckman Coulter CX7 ditekan "F1" kemudian dimasukkan nomor sector yang digunakan, tekan "enter", 4) Identitas bahan yang akan diukur dimasukkan yaitu dengan cara sebagai berikut " tanggal pemeriksaan/bulan pemeriksaan/kode pada sample cup. Misalnya untuk multikalibrator yang diukur tanggal 1 Juni 2005 identitasnya adalah "1/5/B1. Kemudian tekan "enter", 5) Pada komputer alat Beckman Coulter CX7 ditekan "F6". Kemudian dipilih parameter yang akan diperiksa yaitu bilirubin total dan bilirubin direct. Ditekan "enter", 6) Pada layar komputer telah tampil "stand by" maka tekan "start" pada komputer alat. Alat akan melakukan 
pemeriksaan secara otomatis untuk bilirubin total dan bilirubin direct, setelah diperoleh bilirubin total dan bilirubin direct alat akan menghitung kadar bilirubin indirect secara otomatis. Hasil pemeriksaan kadar bilirubin serum bayi dicetak dengan cara menekan "F2" pada kontrol alat, 7) Hasil pemeriksaan bilirubin indirect dalam serum bayi yang telah diperoleh dicatat.

\section{Hasil dan Pembahasan}

Data yang diperoleh selanjutnya dianalisis menggunakan analisis deskriptif. Untuk menentukan persentase kasus hiperbilirubinemia pada bayi yang menderita ikterus neonatus, data kadar bilirubin indirect dibandingkan dengan kadar patologis bilirubin indirect dalam serum. Kadar bilirubin indirect melebihi $12 \mathrm{mg} / \mathrm{dL}$ digolongkan menderita hiperbilirubinemia. Hasil analisis data disajikan seperti pada Tabel 1.

Tabel 1. Perbandingan Kadar Bilirubin Indirect Serum Bayi dengan Nilai Patologis

\begin{tabular}{|c|c|c|c|}
\hline No & $\begin{array}{c}\text { Nama bayi baru } \\
\text { lahir }\end{array}$ & $\begin{array}{l}\text { Kadar bilirubin } \\
\text { indirect }(m g / d L)\end{array}$ & Kategori \\
\hline 1 & Subyek 1 & 9,88 & Normal \\
\hline 2 & Subyek 2 & 7,37 & Normal \\
\hline 3 & Subyek 3 & 10,14 & Normal \\
\hline 4 & Subyek 4 & 12,36 & Hiperbilirubinemia \\
\hline 5 & Subvek 5 & 5,81 & Normal \\
\hline 6 & Subyek 6 & 11,01 & Normal \\
\hline 7 & Subyek 7 & 9,67 & Normal \\
\hline 8 & Subyek 8 & 20,42 & Hiperbilirubinemia \\
\hline 9 & Subvek 9 & 25,11 & Hiperbilirubinemia \\
\hline 10 & Subyek 10 & 8,79 & Normal \\
\hline 11 & Subyek 11 & 13,08 & Hiperbilirubinemia \\
\hline 12 & Subyek 12 & 14,92 & Hiperbilirubinemia \\
\hline 13 & Subyek 13 & 16,71 & Hiperbilirubinemia \\
\hline 14 & Subyek 14 & 9,62 & Normal \\
\hline 15 & Subyek 15 & 12,05 & Hiperbilirubinemia \\
\hline 16 & Subyek 16 & 19,37 & Hiperbilirubinemia \\
\hline 17 & Subyek 17 & 28,7 & Hiperbilirubinemia \\
\hline 18 & Subyek 18 & 12,27 & Hiperbilirubinemia \\
\hline 19 & Subyek 19 & 10,46 & Tidak \\
\hline 20 & Subyek 20 & 11,78 & Tidak \\
\hline
\end{tabular}

Selanjutnya persentase penderita hiperbilirubinemia pada bayi yang mengalami ikterus neonatus dihitung dengan persamaan sebagai berikut.

$$
\begin{aligned}
\% \text { Hiperbilirubinemia } & =\frac{\sum \text { Bayi hiperbilir ubinemia }}{\sum \text { Subyek penelitian }} \times 100 \% \\
& =\frac{10 \text { bayi }}{20 \text { subjek }} \times 100 \% \\
& =50 \%
\end{aligned}
$$

\section{A. Kadar Bilirubin pada Bayi yang Mengalami Ikterus Neonatus}

Berdasarkan data hasil penelitian bilirubin indirect pada Lampiran 3, terlihat bahwa kadar bilirubin indirect serum bayi yang mengalami ikterus neonatus adalah berada pada rentangan $5,81 \mathrm{mg} / \mathrm{dL}$ sampai dengan $28,7 \mathrm{mg} / \mathrm{dL}$. Kadar ini dapat dibedakan menjadi dua golongan yaitu golongan yang mengalami hiperbilirubinemia dan golongan yang tidak mengalami hiperbilirubinemia. Jumlah bayi yang mengalami hiperbilirubinemia adalah 10 bayi. Sedangkan jumlah yang tidak menderita hiperbilirubinemia adalah 10 bayi. Golongan 
hiperbilirubinemia memiliki rentangan kadar bilirubin indirect dari 12,36 mg/dL sampai dengan $28,7 \mathrm{mg} / \mathrm{dL}$. Sedangkan golongan yang tidak mengalami hiperbilirubinemia dari $5,81 \mathrm{mg} / \mathrm{dL}$ sampai dengan $11,78 \mathrm{mg} / \mathrm{dL}$.

Secara teoritis bayi yang mengalami ikterus neonatus akan memiliki kadar bilirubin indirect yang melebihi kadar bilirubin normal $(<2 \mathrm{mg} / \mathrm{dL})$. Hal ini disebabkan karena pada saat masih dalam kandungan, janin membutuhkan sel darah merah yang sangat banyak, dikarenakan paru-paru jabang bayi belum berfungsi secara sempurna. Sehingga sel darah merah tersebut yang berfungsi untuk mengangkut oksigen dan nutrisi dari ibu ke janin melalui plasenta. Sesudah bayi tersebut lahir paru-paru sel darah merah tersebut tidak dibutuhkan lagi. Setelah sel darah merah berlebih ini berumur 120 hari sel-sel darah merah akan mati. Sel-sel darah merah yang telah mati dirombak menjadi bilirubin. Bilirubin ini tidak larut dalam darah sehingga disebut bilirubin tak terkonjugasi (indirect). Bilirubin ini akan terikat pada albumin darah dan keluar dari tubuh bayi melalui plasenta. Pada waktu bayi tersebut lahir plasenta akan terputus, sehingga bayi tersebut harus memproses sendiri bilirubin indirect tersebut menjadi bilirubin direct. Namun organ-organ tubuh bayi belum berfungsi secara sempurna, sehingga bayi tersebut belum dapat memproses bilirubin indirect menjadi bilirubin direct di dalam hati agar dapat dikeluarkan melalui feses dan urin. Hal ini akan menyebabkan terjadinya penumpukan bilirubin di dalam hati dan juga jaringan. Keadaan ini secara fisis diamati sebagai warna kekuningan pada jaringan atau kulit bayi, sklera, dan mukosa.

Pada bayi kadar albumin dalam darah sangat rendah sehingga bilirubin indirect akan beredar ke dalam jaringan secara bebas. Hal ini sangat berbahaya bagi kelangsungan hidup bayi tersebut, bilirubin indirect yang bebas ini masuk ke dalam susunan saraf pusat dan menyebabkan kern ikterus (pelengketan bilirubin di dalam otak), sehingga akan terjadi keterbelakangan mental, ketulian tingkat tinggi, dan gangguan bicara.

Selain itu ikterus neonatus dapat juga disebabkan karena ketidakcocokan (inkompabilitas) golongan darah yang biasanya disebut ketidakcocokan golongan darah (ABO), misalnya golongan darah dari ibu adalah $O$ sedangkan pada bayi bergolongan darah $A$ atau $B$. Kehamilan demikian dimasukkan ke dalam kehamilan yang berisiko. Karena bayi kuning seringkali dilahirkan oleh ibu yang bergolongan darah $\mathrm{O}$, karena golongan darah $\mathrm{O}$ memiliki anti $A$ dan anti B. Sehingga jika golongan darah anak $A$ atau $B$, maka akan terjadi reaksi yang menyebabkan kerusakan sel darah merah. Pada saat masih dalam kandungan, jika darah janin tidak cocok dengan darah ibunya, maka darah ibu akan membentuk antibodi (zat penangkis). Zat antibodi ini sedikit banyak akan mengalir lagi ke tubuh bayi melalui plasenta dan menghancurkan sel darah merah bayi tersebut sehingga meningkatkan kadar bilirubinnya di dalam hati.

Untuk penanganan keadaan ikterus neonatus pada bayi yang kadar bilirubin indirectnya masih rendah, dan masih bersifat sementara dapat dilakukan terapi sinar dengan bantuan sinar matahari. Namun bayi baru lahir jangan dijemur langsung dibawah sinar matahari cukup asal terkena sinar saja. Selain itu, tindakan medis lainnya adalah terapi sinar biru (blue light therapy). Hal ini disebabkan bilirubin sangatlah sensitif terhadap cahaya dan panas sehingga mudah rusak dan terurai yang selanjutnya dengan cepat dibuang melalui urin dan feses.

Jika ikterus neonatus tersebut disebabkan karena faktor patologis (penyakit) seperti pada hiperbilirubinemia akibat ketidakcocokkan Rhesus dan golongan darah (ABO), maka penanganan yang dapat dilakukan adalah tranfusi tukar darah. Selain itu, dapat dilakukan dengan pemberian fenobarbital. Obat ini bekerja sebagai enzyme inducer sehingga konjugasi bilirubin indirect akan dapat dipercepat. Dan lebih mudah dikeluarkan melalui feses, dan urin.

\section{B. Persentase Hiperbilirubinemia pada Bayi yang Mengalami Ikterus Neonatus di Rumah Sakit Sanglah Denpasar}

Dari analisis data diperoleh persentase kasus hiperbilirubinemia pada bayi yang menderita ikterus neonatus di Rumah Sakit Sanglah Denpasar adalah 50\%. Hasil yang diperoleh ini sebanding dengan kasus yang sama yang pernah ada, yaitu di Rumah Sakit Dokter Cipto Mangunkusumo kasus hiperbilirubinemia pada bayi yang menderita ikterus neonatus $62,53 \%$. Dari hasil yang diperoleh kasus hiperbilirubinemia di Rumah Sakit Sanglah Denpasar dari tanggal 1 juni sampai tanggal 14 juni tergolong sedang. Ini berarti banyaknya kasus hiperbilirubinemia pada bayi yang mengalami ikterus neonatus adalah $50 \%$. Hal ini menandakan bahwa gangguan metabolisme bilirubin pada bayi yang diperiksa di Rumah Sakit Sanglah Denpasar tergolong sedang. Hal ini disebabkan pemeriksaan laboratorium terhadap calon suami-istri, untuk mengetahui golongan darah (ABO), dan Rhesus sudah cukup baik. Sehingga kemungkinan bayi terserang hiperbilirubinemia juga tidak terlalu tinggi. Selain itu, bayi 
dalam penelitian ini ketika masih dalam kandungan sudah cukup mendapatkan monitor secara elektris. Sehingga bila terjadi gangguan pada janin dokter dapat melakukan persalinan bedah caesar untuk mengurang resiko bayi cacat akibat kadar bilirubin terlalu tinggi.

\section{Simpulan dan Saran}

Berdasarkan tujuan yang dirumuskan dan hasil penelitian yang diperoleh maka dapat disimpulkan hasil penelitian ini adalah sebagai berikut: 1)Kadar bilirubin indirect serum bayi yang mengalami ikterus neonatus di Rumah Sakit Sanglah Denpasar dari tanggal 1 Juni sampai dengan 14 Juni adalah $5,81 \mathrm{mg} / \mathrm{dL}$ sampai $28,7 \mathrm{mg} / \mathrm{dL}$, 2)Persentase kasus hiperbilirubinemia pada bayi yang menderita lkterus neonatus yang menjadi sampel penelitian adalah $50 \%$.

Adapun saran saran yang ingin disampaikan peneliti terkait dengan penelitian ini adalah sebagai berikut: 1)Mengingat tingginya kasus hiperbilirubinemia pada bayi menderita ikterus neonatus yang serumnya menjadi subyek penelitian ini, maka perlu dilakukan penanganan lebih lanjut bagi bayi yang menderita ikterus neonatus agar kadar bilirubin indirectnya lebih terkontrol, 2)Sebaiknya dilakukan pemeriksaan rutin terhadap suami-istri dan ibu-ibu yang mengandung agar dapat dicegah terjadinya kasus-kasus ikterus neonatus.

\section{Daftar Pustaka}

Anonim. 2004. Sop Kimia Klinik Rumah Sakit Sanglah Denpasar. Denpasar: Instalasi Laboratorium Patologi Klinik Rumah Sakit Sanglah Denpasar

Arimas, D. 2000. Pengaruh Penundaan Tes, Cahaya dan Temperatur Penyimpanan Terhadap Kadar Bilrubin Serum. Makasar Program Pasca Sarjana:UNHAS

Bakta, I. M. 1995. Buku IImu Penyakit Dalam Dasar. Denpasar; UNUD

Hasan, R. et. al. 1985. Buku Kuliah Ilmu Kesehatan Anak 2 .Jakarta:Universitas Indonesia

Hardjono et. al. Interpretasi Hasil Tes Laboratorium Diagnostik. Makasar:Lembaga Penerbitan UNHAS

Hasan, Rusepno et. al. 1985. Buku Kuliah Ilmu Kesehatan Anak 3 . Jakarta:Universitas Indonesia

Murray, R. K. 1996. Biokimia Harper. Jakarta: ECG

Nis, A. 2005. " Bayi Kuning” Dalam Sugiono (Ed) Intisari. Jakarta: Intisari Mediatama

Styrer, L. 1996. Biokimia Volume 2. Jakarta: ECG

Wiknjosastro, H. 1997. Buku Kuliah Ilmu Kebidanan Edisi 2. Jakarta: Yayasan Bina Pustaka Sarwono Prawirohardjo 